\title{
MASSIVE OCULAR HEMORRHAGE RESULTING IN BLINDNESS IN A PATIENT WITH THE SICKLE CELLTRAIT WHO DEVELOPED LEPTOSPIROSIS. CASE REPORT
}

\author{
Everaldo COSTA(1,2), Antonio Alberto LOPES(3), Edilson SACRAMENTO(1,2) \& Paulo Afonso B. SANTOS(4)
}

\begin{abstract}
SUMMARY
This case report describes the findings of a 18 year-old black male from Bahia, a Northeastern state in Brazil, with the sickle cell trait, who developed bilateral hyphema and vitreous hemorrhage with blindness in the course of leptospirosis. The patient started to complain of blurred vision four days after the start of fever and muscular pain and approximately twelve hours after the introduction of penicillin. The severity of the leptospirosis in conjunction with sickle cell trait was considered to be the most likely explanation for this ocular complication.
\end{abstract}

KEYWORDS: Leptospirosis; Hyphema; Vitreous hemorrhage; Blindness.

\section{INTRODUCTION}

Lung and gastrointestinal hemorrhage are common complications and important contributors for death among patients with leptospirosis who need hospitalization ${ }^{8-10}$. Ocular hemorrhage, mainly conjunctival, has also been described in association with this infectious disease $e^{7,11,12}$; however, to our knowledge, this complication has not been reported as a cause of blindness. The objective of this report is to describe the findings of a young patient with sickle cell trait who developed a massive bilateral vitreous hemorrhage followed by blindness and phthisis bulbi in the course of leptospirosis. It is possible that, in this patient, the presence of the sickle cell trait has facilitated this uncommon complication of leptospirosis.

\section{CASE REPORT}

A 18 year-old black male, warehouse worker, was admitted to an infectious disease hospital (Couto Maia hospital) located in the city of Salvador, Northeast Brazil, during an outbreak of leptospirosis. He was well until four days before hospital admission when fever and myalgia developed abruptly. At the fourth day of symptoms, he was coughing with mucous and blood-stained sputum. He denied prior jaundice and was not aware of any hereditary disease in his family. On examination the patient was found to be profoundly icteric (IV/IV) with conjunctival hyperemia, typical of leptospirosis. A macroagglutination was positive for this infectious disease. The initial treatment included parenteral fluids, intravenous penicillin $\mathrm{G}, 1$ million units $\mathrm{q} 4 \mathrm{~h}$. The patient developed acute renal failure (serum creatinine of $6.4 \mathrm{mg} / \mathrm{dL}$ ), but dialysis was not necessary. The hemoglobin electrophoresis revealed an AS pattern. The main laboratory findings are shown in the Table 1.

Approximately twelve hours after admission the patient complained of blurred vision. It was also observed epistaxis. On the fourth hospitalization day a marked reduction in the visual acuity was reported. During ophthalmic examination it was revealed that the patient had bilateral vitreous hemorrhage. One month after the onset of the clinical manifestations of leptospirosis, the patient complained of strong pain in both eyes. Another ophthalmic examination showed amaurosis, corneal edema and total hyphema. The ultrasonographic examination revealed massive vitreous hemorrhage and retinal detachment in both eyes (Figures $1 \mathrm{~A}$ and $\mathrm{B})$. These findings were interpreted as complications of the episode observed on the fourth day rather than a second episode of vitreous hemorrhage. A carbonic anhydrase inhibitor and eye drops of a beta-blocker was started to reduce the intraocular pressure that reached $40 \mathrm{~mm} \mathrm{Hg}$. Later the patient developed wasting and shrinkage of the eyeballs, characterizing a picture of phthisis bulbi.

\section{DISCUSSION}

It is important to note that the patient described in this report in addition to leptospirosis was also positive for the sickle cell trait. In fact, sickle cell retinopathy is reported as a major cause of spontaneous vitreous hemorrhage ${ }^{1,4}$. Moreover, the sickle cell trait is considered a risk factor of secondary hemorrhage in blacks with traumatic hyphema ${ }^{13}$. In a Brazilian sample of 63 patients with SC and SS hemoglobinopathy, proliferative retinopathy and atrophic retinal tears were described in a

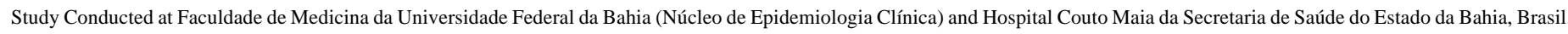

(1) Associate Clinical Professor, Department of Medicine, Escola Bahiana de Medicina e Saúde Pública, Salvador, BA, Brasil.

(2) Attending Physician in Infectious Disease, Hospital Couto Maia, Salvador, BA, Brasil.

(3) Associate Clinical Professor, Department of Medicine, Universidade Federal da Bahia, Salvador, BA, Brasil.

(4) Associate Professor, Department of Ophthalmology, Universidade Federal da Bahia, Salvador, BA, Brasil.

Correspondence to: Antonio Alberto Lopes, Rua Mar. Floriano 448, apt. 1301, Canela, 40110-010 Salvador, Bahia, Brazil 


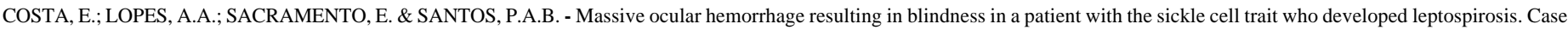
report. Rev. Inst. Med. trop. S. Paulo, 42(5): 287-289, 2000.

\section{Table1}

Laboratory findings on admission and during follow-up

\begin{tabular}{|c|c|c|c|c|c|}
\hline Variable & On Admission & Day 2 & Day 5 & Day 29 & Day 50 \\
\hline $\begin{array}{l}\text { Hematocrit }(\%) \\
\left.\text { White cell count (per } \mathrm{mm}^{3}\right)\end{array}$ & 30,000 & & & 9,200 & 8,000 \\
\hline $\begin{array}{c}\text { Differential count }(\%) \\
\text { Neutrophils } \\
\text { Band forms } \\
\text { Metamyelocytes } \\
\text { Myelocytes } \\
\text { Lymphocytes } \\
\text { Eosinophils } \\
\text { Monocytes }\end{array}$ & $\begin{array}{r}73 \\
3 \\
3 \\
3 \\
15 \\
1 \\
4\end{array}$ & & & & \\
\hline Platelet count (per $\mathrm{mm}^{3}$ ) & & & & 225,000 & \\
\hline Prothrombin time ( $\%$ of control) & & & & 81 & \\
\hline Urea $(\mathrm{mg} / \mathrm{dL})$ & 263 & 142 & 94 & 22 & 23 \\
\hline Creatinine (mg/dL) & 6.4 & 2.4 & 2.1 & 1.2 & 0.5 \\
\hline Sodium (mmol/L) & 138 & & & 136 & \\
\hline Potassium (mmol/L) & 3.3 & & & 4.1 & \\
\hline Aspartate aminotransferase (U/L) & 100 & & & 48 & 10 \\
\hline Alanine aminotransferase (U/L) & 120 & & & 50 & 6 \\
\hline $\begin{array}{c}\text { Bilirrubin }(\mathrm{mg} / \mathrm{dL}) \\
\text { Total } \\
\text { Conjugated }\end{array}$ & $\begin{array}{l}47.2 \\
28.3\end{array}$ & & & $\begin{array}{l}4.9 \\
4.2\end{array}$ & $\begin{array}{l}1.4 \\
1\end{array}$ \\
\hline
\end{tabular}
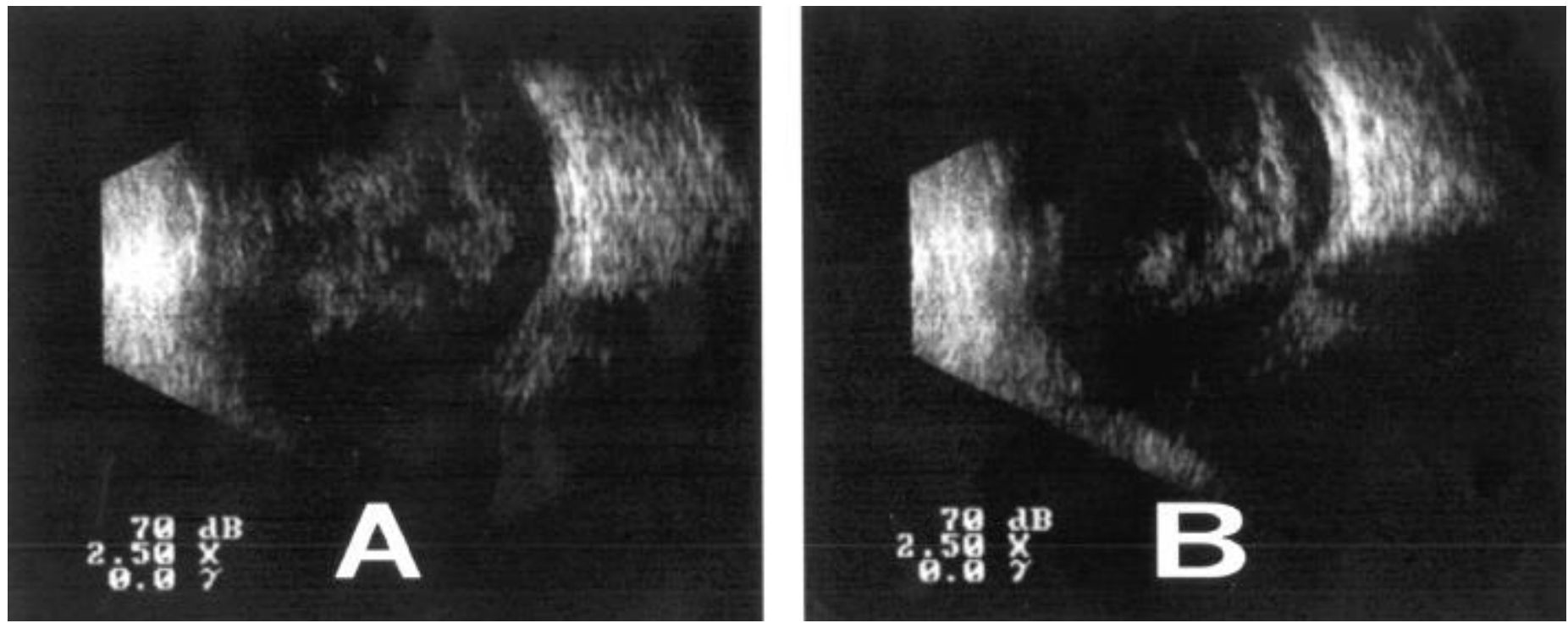

Fig. 1 - Ocular ultrasonography - detachment of the retina in the right (A) and left (B) eye 


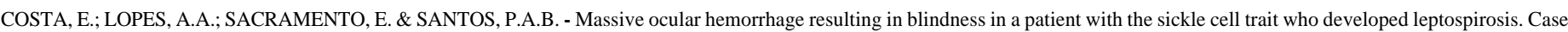
report. Rev. Inst. Med. trop. S. Paulo, 42(5): 287-289, 2000.

large fraction of patients ${ }^{2}$. Thus, there is evidence to support the influence of the sickle cell gene on the ocular complication that is here described.

Leptospirosis should also be viewed as a potential contributor to the ocular findings described in the present report, considering the susceptibility to bleeding in patients with this infectious disease ${ }^{9}$. In fact, retinal vasculitis and hemorrhage have been described in association with leptospirosis ${ }^{11}$. There is evidence that the hemorrhagic diathesis in this infectious disease is, at least in part, due to vascular damage, mainly capillary ${ }^{5}$. Thrombocytopenia is also common and could contribute to hemorrhagic complications in some patients ${ }^{6,14}$. Unfortunately, in the present case it was not investigated the presence of coagulation disorders when the ocular hemorrhage was detected. The platelet count was normal, but it was performed later when the clinical manifestations of leptospirosis have subsided. It is also possible that the renal failure had contributed to the predisposition to hemorrhage.

Despite the predisposition to bleeding, no previous report of blindness due to vitreous hemorrhage and hyphema in human leptospirosis was found in a systematic search of the MEDLINE database from 1966 to present. Based on the literature review, it was concluded that the occurrence of an ocular complication similar to this one is also not common in subjects with the sickle cell trait. It is possible that, in this patient, the combination of the two conditions, sickle cell trait and leptospirosis, contributed to the development of a severe ocular hemorrhage resulting in blindness. A prospective study is needed to assess the role of this potential interaction between the sickle cell gene and leptospirosis in determining ocular hemorrhagic complications. This is an important question, particularly for areas, like Northeast Brazil, where the sickle cell gene is highly prevalent and outbreaks of leptospirosis are very common ${ }^{3,15}$.

\section{RESUMO}

\section{Hemorragia ocular intensa ocasionando cegueira em paciente com estigma falciforme que desenvolveu leptospirose. Relato de caso}

Este relato de caso descreve os achados em homem negro com 18 anos de idade, da Bahia, estado do nordeste do Brasil, com estigma falciforme que desenvolveu hifema bilateral e hemorragia vítrea com cegueira no curso de leptospirose. O paciente começou a se queixar de visão embaçada quatro dias após o início da febre e da dor muscular e aproximadamente 12 horas após o início da penicilina. A gravidade da leptospirose em conjunto com o estigma falciforme foi considerada a mais provável explicação para esta complicação ocular.

\section{REFERENCES}

1. BONANOMI, M.T. - Neovascularização da retina em hemoglobinopatia SC e hemorragia vítrea. Arq. bras. Oftal., 60: 24-33, 1997.

2. BONANOMI, M.T.; CUNHA, S.L. \& ARAUJO, J.T. de - Funduscopic alterations in SS and SC hemoglobinopathies. Study of a Brazilian population. Ophthalmologica (Basel), 197: 26-33, 1988.

3. CALDAS, E.M. \& SAMPAIO, M.B. - Leptospirosis in the city of Salvador, Bahia, Brazil: a case-control seroepidemiologic study. Int. J. Zoonoses, 6: 85-96, 1979.

4. DANA, M.R.; WERNER, M.S.; VIANA, M.A. \& SHAPIRO, M.J. - Spontaneous and traumatic vitreous hemorrhage. Ophthalmology, 100: 1377-1383, 1993.

5. DE BRITO, T.; BOHM, G.M. \& YASUDA, P.H. - Vascular damage in acute experimental leptospirosis of the guinea-pig. J. Path., 128: 177-182, 1979

6. EDWARDS, C.N.; NICHOLSON, G.D. \& EVERARD, C.O. - Thrombocytopenia in leptospirosis. Amer. J. trop. Med. Hyg., 31: 827-829, 1982.

7. FARR, R.W. - Leptospirosis. Clin. infect. Dis., 21: 1-6, 1995.

8. LESSA, I. \& CORTES, E. - Cerebrovascular accident as a complication of leptospirosis [letter]. Lancet, 2: 1113, 1981.

9. LOMAR, A.V.; VERONESI, R.; BRITO, T. \& DIAMENT, D. - Leptospiroses. In: VERONESI, R. \& FOCACIA, R., ed. Tratado de Infectologia. São Paulo, Atheneu, 1996. v. 2. p. $987-1003$.

10. MACEDO, I.; FIGUEIREDO, J.; CARVALHO, E. \& BARBOSA, E. - Coagulação intravascular disseminada na leptospirose. Rev. Pat. trop., 2: 363-366, 1973.

11. MARTINS, M.G.; MATOS, K.T.; DA SILVA, M.V. \& DE ABREU, M.T. - Ocular manifestations in the acute phase of leptospirosis. Ocul. Immunol. Inflamm., 6: 75-79, 1998.

12. MURDOCH, D. - Leptospiral uveitis. Trans. ophthal. Soc. N. Z., 32: 73-75, 1980.

13. NASRULLAH, A. \& KERR, N.C. - Sickle cell trait as a risk factor for secondary hemorrhage in children with traumatic hyphema. Amer. J. Ophthal., 123: 783-790, 1997.

14. NICODEMO, A.C.; DEL NEGRO, G. \& AMATO NETO, V. - Thrombocytopenia and leptospirosis. Rev. Inst. Med. trop. S. Paulo, 32: 252-259, 1990.

15. SALZANO, F.M. - Incidence, effects, and management of sickle cell disease in Brazil. Amer. J. pediat. Hemat. Oncol., 7: 240-244, 1985.

Received: 11 April 2000

Accepted: 19 June 2000 